\title{
Suggesting a Tailored Career Guidance Program in Egyptian Tourism and Hotels High Institutes
}

\author{
Nahla Mohamed Helmy ${ }^{1}$ \\ Michael Magdi Zaki ${ }^{2}$ \\ ${ }^{1}$ High Institute of Tourism, Hotels and Restoration, Abou Qir, Alexandria \\ ${ }^{2}$ Faculty of Tourism and Hotels, Luxor University
}

\begin{abstract}
Career Guidance Program is a comprehensive development program that assists students in educational institutes to determine their career choices and decisions. It also helps them to acquire the field knowledge and skills in order to identify the appropriate selection, explore alternatives and succeed in the labor market. The paper aims at developing a recognized policy for career guidance program in Egyptian high institutes of tourism and hotels, especially after dictating the new study plan starting from the education year of $2017 / 2018$. Field survey study has been carried out through selecting a sample of 3 tourism and hotels high institutes, taking in consideration the geographical distribution. To reach paper's objectives, a questionnaire form has been distributed among 170 students. However, only 142 valid questionnaires were received. Moreover, an interview has been conducted with 12 academic staff working in the sampled institutes with different specialties. Furthermore, a suggested career guidance model has been developed with reference to 9 reputable international academic associations and also reviewed and accepted by the 12 interviewed academic staff. Research's results prove the need for career guidance program in the Egyptian tourism and hotels high institutes to assist students in selecting their specialty and facilitate the process of career selection. Finally, it is recommended that the Ministry of Higher Education (MHE) should set an obligatory career guidance program in the Egyptian tourism and hotels high institutes, taking in mind the proposed model as a guideline platform. In addition, the institutes have to build a career guidance unit with the involvement of tourism industry's stakeholders, taking into account the on-line career guidance activities, career counseling sessions, quality standards and sustainable development.
\end{abstract}

Keywords: Suggesting, Tailored, Career Guidance Program, Egyptian, Tourism and Hotels and High Institutes

\section{Introduction}

Many career guidance units have been established years ago in universities, involving the professional experience in career guidance and counseling (Li, 2002 and Ma, 2009). Educational experts are challenging for applying successful career guidance program to enrich students with appropriate career management skills and assisting them in career decision making. Moreover, career guidance system is an echo of the social background, because it provides the students with the domestic labor-market needs and links it to education (Sultana \& Watts, 2008). The purpose of integrating career guidance and counseling with the school regime is to reduce the unawareness of many fresh graduates about their career options and opportunities (Oye et al., 2012). The career guidance program plays a key role as an entry process to form the link between education and labor market (Allan et al., 2013). Moreover, university career services play a pivotal role in qualifying students to find their appropriate jobs that match their abilities and skills (Fabio and Bernaud, 2008). Bivand (2012) confirms this issue by stating that career guidance has a strong influence on fresh graduates' employability since the main problem of such graduates is not only finding a job, but also finding a suitable and constant secured job. James and Devlin (2006) and Aird et al., (2010) stated that career guidance supports university admission by increasing students' awareness about the education they will learn. It assists 
students to get familiarized with all information about university education and academic courses, and their benefits on students' future work life. Information provided to students are addressing courses' contents, duration, career options, completing specific subjects and data related to test-score grades, academic staff contacts, exams deadlines and official required forms. Radulet (2013) highlighted that there is an urgent need for occupational guidance and counseling services to help students exploring their interests, abilities, skills and values, and also support them with the advice and consultation related to future work life planning. Gore et al., (2015) also stated that career guidance aims at providing the effective consultation to students for planning their work life and career development after graduation.

\section{Review of Literature}

\section{What is Career Guidance?}

Brown (2007) mentioned that career guidance in higher education represents the activities done to assist students in determining their educational, training and occupational choices and help them in understanding their desires, interests and capabilities. It is also the program that provides students with the information required for making decision of their career among different choices. Generally, career guidance program is designed to provide students with the up-to-date information about their educational varieties, studies' development, field prospects and job careers, certification and recognition (Erasmus et al., 2009). Career guidance and orientation services are implemented for the purpose of helping learners, at different ages, to choose their education, training and job opportunities and also to determine their work profession (Watts and Fretwell, 2004).

The Terminology of (Career Planning) or (Employment Guidance) are utilized when mentioning career guidance, career education and occupational guidance. They demonstrated the discrepancy between the two terminologies in the learning background. Employment guidance is related to the matters of finding jobs for fresh graduates in terms of awareness of the occupational standards, knowledge of job recruitment procedures, job admission and selection criteria. On the contrary, job career planning is defined as guidance provided to students that match their own conditions so to help them in planning for their future career development (Wang, 2008 and $\mathrm{Wu}$, 2008).

\section{Need for Career Guidance Program}

Career guidance has an economic value in some renowned worldwide colleges. Although the career guidance services are performed for free, students are still ready to pay against such efforts as they really need individual career counseling and services (Choi et al., 2013 and Crisan et al., 2015). Generally, career guidance supports learners with all information required for career choices to meet their personal skills and, attitude and behavior (Coetzee and Roythorne, 2012). The absence of students' awareness about their career choices is resulted from the inefficiency of applied career guidance program, which is manifested in many changes, unsolved educational problems and poor score-grades of students (Kunnen, 2013).

A study done by Leach and Patall (2013) proves that the unawareness of students about their career opportunities and prospects, leads to the loss of enthusiasm in learning as well as making a wrong decision in their career choice. Similarly, a recent study conducted by Khamadi et al. (2011), pointed out that students' career immaturity results in inappropriate occupational choices which do not meet their skills, interests, and desires. Furthermore, the non-existence of career guidance in colleges causes the wrong selection of professions, which mostly selected by 
students' parents rather than students themselves, regardless of their capabilities, knowledge, and professional background. Hunt and Eisenberg (2010) mentioned that learners usually seek career guidance services to decrease the confronted psychological health problems and learning difficulties. Moreover, Adams (2012), stated that students are in an actual need for career guidance and counseling services as it is highly significant for their educational and future career decision-making such as selection of academic courses, educational activities, researching processes and job skills.

\section{Benefits of Career Guidance}

There are two important benefits of career guidance 1) to upgrade the performance in the labor market and 2) to control the growing percentage of unemployment, poor and unprofessional performance of fresh graduates (West, 2013). Career guidance assists in eliminating the common students' mistakes and confusion in career selection and career development, and in identifying their prospective abilities as competitive advantage for filling job vacancies in the labor market. Professional career guidance provides plans with a long-standing vision for career development, from which students are profited by acknowledging their actual and appropriate future work life (Guo, 2009). Career guidance is also providing support in education reform, which consequently increases the employability. Students and families are not only the beneficiary bodies who are benefited from career guidance, but the university itself and the society are benefited as well (Li and Ye, 2001). It is advised that the Ministry of Education should set up devices to support students with the sufficient information about their occupational ladder of progression, starting from the lower to the higher grade of learning. Moreover, this will assist them to upgrade their knowledge with the latest career information and data and will also contribute to their educational selection (Mporananayo and Andala, 2018). Career guidance can have a positive effect on economic and labor market system, on educational and social level, involving young people career transfer, skills deployment and contribution in academic learning (Hooley, 2017). An effective career guidance program is lucrative in the fact that it boosts the proficiency of education and training system pertaining to the business market. Accordingly, the professional career guidance program can enhance employability, in sense of meeting supply with demand (Long and Hubble, 2018). In addition, career guidance is profitable since it makes learners ready for choosing their career and have the ability to plan their future work life and process the correct field transfer within any type of business (Sun \& Yuen, 2012).

\section{Career Guidance Stakeholders}

Learners are joining career guidance programs for further understanding about the appropriate career options (Hiebert et al., 2001). Students' parents are one of the career guidance stakeholders that might be considered in the program framework (Mporananayo and Andala, 2018). The Academic staff is also very important as active career guidance stakeholders. This is owing to the fact that they are the first academic contact with students who possess adequate knowledge about the potential career and opportunities. Thus, the academic staff is very effective in career choice (Lamport, 1993). On the contrary, Alexitch (2002) stated that the frequent interaction between the staff and students support in taking the right career decision. Nauta et al. (1998) study clarified that academic staff communication influence indirectly students' career choice, which is better than any other consultants' advice. Undergraduates in Alexitch and Page's (1997) study pointed out that acquiring the career knowledge should be acquired through two channels: faculty members and field consultants. However, still students prefer to receive career 
information from their professors which actually give them the real motivation and positive power. This is because students mostly see that professors' advisor is highly significant than any other advisors or consultants.

\section{Career Guidance Methodology and Implementation Mechanism}

Public awareness campaign in the form of seminar, public lectures, and workshops should be organized to sensitize students, universities management, government agencies, lecturers/teachers and the public on the need for career guidance services. Students should understand well the role of career guidance and counseling that they follow so as to utilize the advice they receive from career guidance counselors. This will enable them to improve their concentration in studying and improve their academic performance (Mporananayo and Andala, 2018). Career guidance and counseling provide the occupational and academic information to students so as to let them understand the different career opportunities before taking their decision. The counselor assists students to identify their professional career personality and to foresee their individual future (Coetzee and Roythorne, 2012). Career guidance has different platforms, from direct individual counseling to group counseling, and from official to unofficial consultation. Undergraduate students look for getting profession's knowledge from different springs like friends, parents, college, and the internet (Vertsberger \& Gati, 2016). Career guidance in universities is mainly carried out through "career units" and conducted by professional instructors (Long and Song, 2007). In China, a 'three-path education pattern' is implemented (1) 'education for path of majors' and it is done by entering the university, (2) 'education for condition consciousness' (3) 'education for selecting professions' and it is done during students' graduation (Yu, 2008).

Peterson et al. (2001) provided a very good example of career guidance program in the United States, which is called the Occupational Information Network. This Career guidance method depends on the fact that universities seek an applicable and reliable career guidance program that meets students' requirements and benefits. Accordingly, it is important to build a network of resources and assets to develop a detailed career guidance program. Sun (2009) clarified another example which is called on-line course innovated by Fudan University in China. Students at this university watch 50 various video classes as a part of on-line career program. This process is done through usernames and passwords. This e-class contains four stages: career evaluation, professions identification, curriculum study, and career consultation. Zhao and Shen (2008) provided another on-line career guidance program model. They stated that due to the shortage of professional experts in career guidance, some universities constructed educational networks for students such as career guidance program website, free manuals, and arranged meetings. Moreover, Yan (2008) reported that 'experimental-career guidance model' is utilized in number of universities. This involves replicated job interviews and providing success stories of occupational experiences. Internships and business partnership in some properties is also provided so as to visualize to students an actual priceless career options. Normally, providing such cases outside the university campus is not an easy task and hardly arranged in cooperation with different companies and associations working in the market. Mulvey (2010) as well as Wooley and Hooley (2015) stated that the main functions of career guidance should be managed in a chronological way in colleges with emphasis on pre-entry support, support during courses and support at finalizing the course. These career guidance activities should be done favor students during their overall study period in the college. Moreover, Hughes et al. (2016) supported such chronological activities but adding that they must be integrated with support from 
the labor market that assists a great deal in determining students' career decision. Gibson et al. (2015) highlighted labor market support by stating that it adds value to students' selection. This support is exemplified in face-to-face dialogue, guest speakers' visits, and students' visits to the workplace. In addition, it is important to have access to the most valuable and specialized career guidance websites together with university's printed handouts such as manuals, guides, handbook, and pamphlets/brochures.

\section{Career Counseling}

Career counseling is an active tool for minimizing career suffering. It is regarded as a continuous, frontal communication between the advisor and student, as the work-field is the first priority for students' interest and concern (Choi et al., 2010). Career counseling has become a progressively proper method for forming the labor world within the framework of life-long-learning (Hartung, 2010). Counseling activities are done through individual consultations, seminars, training and group consultation to identify students' interests and requirements (Chircu, 2014). In a study done by Ferrera et al. (2017) about students' approaches towards career counseling, it is approved that females appreciated and respected career counseling rather than males that recorded more or less negative approaches towards career counseling. Personal humiliation in males decreases the positive attitude towards career counseling. Watts and Van Esbroeck (2000) as well as Sun and Yuen (2012) stated that career counseling is a necessary part of career guidance's plan. However, it is required to be done in a professional manner and on a wider range. New counselors require recent technological methods for implementation such as computerized assessment, self-assessment process and e-counseling.

Career counseling is the process of identifying students' needs and desires as well as guide them to select their vocational career, taking in consideration their strong and weak points, as well as resources and career choices. Students always need proficient career counselors to provide them with the adequate awareness about their desires, needs, capabilities, vision and defects, as well as evaluate their vocational opportunities such as market needs, field competencies, employment needs and job profile (Kok \& Low, 2017). Furthermore, they need to build a career strategy depending on career knowledge, setting and realizing career objectives, and supporting their skills in job-searching (Getachew and Gobena, 2016). Thus, the career counseling role is helping students to choose the most appropriate career that match their knowledge and skills, needs and culture for life-long satisfaction (Santilli et al., 2017). Career counseling and occupational guidance is interrelated to employability to assist employers in acquiring competitive advantage. This is why employers are cooperating with universities and institutes in developing career counseling within developed countries. Universities in developed countries are arranging seminars, workshops, meetings and industrial tours to attain more awareness about the market and work-life (Seung, 2014). Arshad et al. (2018), reported that career counseling is significant in identifying students' knowledge, culture, needs, objectives, desires, and job-searching skills. However, career counseling is still weak and insufficient globally. This is owing to the fact that students are not able to find the sources for getting job-related information. This leads to shortage in potential career opportunities and weak performance. Sun \& Yuen (2012) as well as Cardoso et al. (2012) and Murdock et al. (2012) reported that the main difficulties facing career guidance units are scarcity of organized career counseling and inadequate number of experts working within such units. These difficulties influence negatively the excellency of offered services and the late entering of career-counseling activities. 


\section{Career Guidance in Tourism and Hospitality Industry}

$\mathrm{Gu}$ et al. (2007) prepared a study about students' perception of tourism and hospitality career guidance. Study results clarified that students are not optimistic about their career development since tourism and hospitality industry is not a promising career. Accordingly, graduates select working in other fields due to the low salaries and wages in tourism and hospitality establishments. On the contrary, Baum (1995) and ILO (2001) stated that tourism sector provides a lot of job opportunities for highly skillful graduates as tourism is an international industry that is available in many countries and provide more job opportunities rather than other industries. $\mathrm{Ng}$ and Burke (2006) confirmed that university graduates who are well-educated, professionally trained and have enough awareness about their tourism and hospitality career development are the most promising and potential caliber that are easily employed in the tourism and hospitality labor market. Smith (2001) mentioned that tourism and hospitality students must have enough information about the workplace. This information is acquired through a suitable career guidance support. Moreover, Leppel (2001) pointed out that students that select correctly their academic majors are those students that built properly their work life's objectives in tourism and hospitality field.

Roney and Oztin (2007) reported that current tourism and hospitality students are the future manpower in hotels, travel agents and tourist associations. Accordingly, it is highly important to increase students' awareness about their career path. In a study prepared by them through a sample or 450 Turkish students learning tourism and hospitality, it has been approved that students' perception about their career are very poor due to the lack of career guidance support services. Hence, it is very important to stress on a professional career guidance program during their study.

\section{Research Methodology}

The paper is discussing the possibility of applying a career guidance program in Egyptian tourism and hotels high institutes as they are in a real need for setting such a program. This need is identified through a pilot study with some academic staff working in a number of tourism and hotels high institutes. The main objective of the paper is to prepare a framework of a newly identified career guidance program so as to be tailored to match the education system and contents of the newly dictated study plan in tourism and hotels high institutes, to be presented to the authorized associations for approval and application.

The population of the study includes both students of the second year in the academic year of 2018/2019 and the academic staff working in the selected 3 tourism and hotels high institutes in Egypt. The institutes are selected taking in consideration the geographical distribution to represent the following governorates: Cairo, Alexandria and Luxor. Two methodological tools have been tackled which are questionnaire and interview. The questionnaire and interview lasted for three months from first of October 2018 till end of December, 2018. Moreover, a career guidance program model has been developed and tailored through referencing to career guidance programs in renowned worldwide academic associations, and then reviewed by academic staff working in the three sampled institutes.

First, 170 questionnaire forms have been distributed among second year students in the sampled institutes and 142 questionnaires with valid answers have been received representing $83.52 \%$ of the total number of students. The second year students are selected because they are the first students that study the courses of the newly applied study plan which has been formally dictated in the academic year of 2017/2018. The new study plan consists of various specialties and 
elective courses with different options, the fact that increases students' confusion in choices and maximize the need for career guidance unit to assist students in selection process. The main purpose of the questionnaire is to answer the 6 questions of the study which stated as follows:

1.What is the extent of career guidance significance and need in Egyptian tourism and hotels high institutes?

2. What is the extent of students' awareness about career guidance at Egyptian tourism and hotels high institutes?

3.What are the challenges and problems that face students while choosing their specialty at Egyptian tourism and hotels high institutes?

4.What are the most appropriate methods proposed for career guidance at Egyptian tourism and hotels high institutes?

5.What are the common reasons behind students' selections of their specialty/departments?

6.Is there significant correlation between reasons behind choosing specialty and, challenges and problems that face students while choosing their specialty at Egyptian tourism and hotels high institutes?

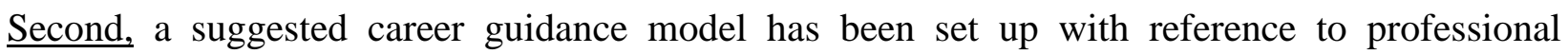
practices of career guidance programs in (9) renowned worldwide academic associations to build the career guidance framework, together with the revision and acceptance of the interviewed academic staff. The criteria of choosing the international academic associations regard the following:

- Some of them are similar in educational culture like Arab associations of Sultan Qaboos University and Qatar University

- Some of them are international academic associations located in Egypt such as American University and German University in Cairo

- One of them is specialized in the same tourism and hospitality career like Glion Institute of Higher Education in Switzerland

- Some of them are located in reputable countries which are known for education development and progress like Kyoto university in Japan

- The contents of the model consist of the 10 components which are clarified and summarized in figure 1.

Third, the interview has been done with 12 academic staff working in the 3 tested institutes as 4 interviewees per each institute. The main objectives of the interview are:

- Confirm the support of the academic staff to the idea of setting a career guidance program in their institutes,

- Identify the main difficulties that may confront the program of career guidance, according to academic staff point of views

- Identify the recommendations of the academic staff for setting up a career guidance program in their institutes

- Provide the comments and feedback of the academic staff on the proposed model of a tailored career guidance program. 
International Journal of Heritage, Tourism and Hospitality Vol. (13), No. (2), September, 2019 By: Faculty of Tourism and Hotels, Fayoum University

Figure 1: Career Guidance Program Model in Tourism and Hotels High Institutes

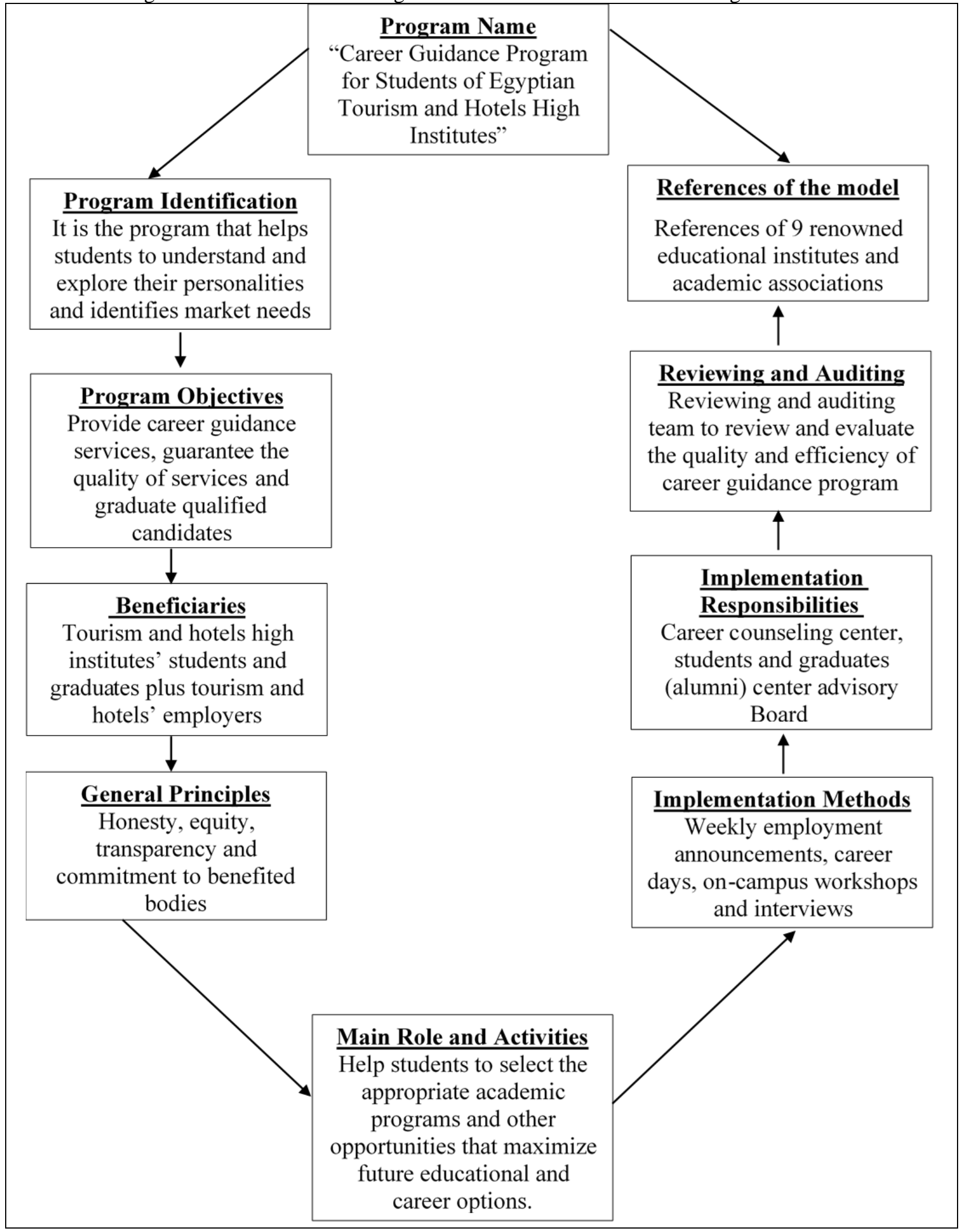




\section{Results and Discussions}

\section{First: The Questionnaire}

The following statistical tests have been used to analyze selected data of the research:

- Cochran's formula

- Levene's test

- Means and standard deviation

- Pearson correlation
- Cronbach's alpha

- Confidence interval for mean

- One sample T test

\section{The sample of the study}

To calculate the suitable sample of the study, data collected from a pilot study have been analyzed using SPSS 20 statistical package as follow:

Table 1: Analysis of the pilot study for the data of the Egyptian tourism and hotels high

\begin{tabular}{|l|l|l|l|}
\hline$\sigma^{2}$ & institutes' students \\
\hline 0.09436 & 1.96 & $\mathbf{C}$ & Levene's Sig. \\
\hline
\end{tabular}

Table (1) shows that Levene's coefficient is not significant Sig=0.088. The Cochran's formula of sample size has been used to calculate the research sample size as follow (Shkeeb, 2014):

$$
n=\frac{Z^{2} \sigma^{2}}{e^{2}}
$$

Where:

$\sigma^{2}$ : Variance of community $Z$ : standard degree $\mathbf{e}$ : maximum allowed error From the previous formula and table (1) an appropriate sample size for this research has been calculated, where the maximum allowed error $(\mathbf{C})$ was 0.05 , this value is suitable for discrete data (Shkeeb, 2014), standard degree ( $Z$ ) was 1.96 and the variance of the sample $\left(\sigma^{2}\right.$ ) was 0.088. Applying these values to the Cochran's formula reveals that the appropriate sample size for this research is 145 participants. A total of 170 questionnaire forms were distributed to students, only 142 students positively shared the questionnaire, which represent $(97.9 \%)$ of the appropriate sample size for this research.

\section{Sample characteristics}

Table 2: Sample characteristic

\begin{tabular}{|l|l|l|l|}
\hline Variable & Characteristic & Freq. & $\%$ \\
\hline \multirow{2}{*}{ Latest qualification } & General Secondary School Certificate & 38 & $26.7 \%$ \\
\cline { 2 - 4 } & Technical Secondary School Certificate & 104 & $73.3 \%$ \\
\hline \multirow{2}{*}{ Gender } & Male & 91 & $64 \%$ \\
\cline { 2 - 4 } & Female & 51 & $36 \%$ \\
\hline \multirow{2}{*}{ Department } & Tourism and hospitality & 129 & 90.8 \\
\cline { 2 - 4 } & Tour guidance & 13 & 9.2 \\
\hline
\end{tabular}

The results of the survey showed in table (2) proved that most of the students' sample (73.3\%) represents the holders of technical secondary school certificate and just (26.7\%) of the sample represents the holders of general secondary certificate. As well, $(64 \%)$ of the sample was male but $(36 \%)$ of the sample was female. Finally, major of the sample $(90.8 \%)$ categorized as tourism and hospitality department students, and just (9.2\%) of the sample classified as tour guidance department students. 


\section{Validity and Reliability}

The survey was piloted on a sample of 30 students of Egyptian tourism and hotels high institutes to test its contents validity. Then the questionnaires were modified according to respondents' comments. Cronbach's Alpha coefficient was calculated and exceeded 0.7 for all items; this means that all items are valid (Henson, 2001). Details for all dimensions' values of Cronbach's alpha are provided in table (3).

Table 3. The internal reliability of the study dimensions

\begin{tabular}{|l|l|l|}
\hline Dimension & No. of Items & Cronbach's alpha \\
\hline Career guidance significance & 2 & 0.81 \\
\hline Career guidance awareness & 2 & 0.77 \\
\hline Reasons behind choosing specialty & 5 & 0.70 \\
\hline Difficulties during selecting specialty & 5 & 0.88 \\
\hline Methods of career guidance & 5 & 0.78 \\
\hline
\end{tabular}

\section{Descriptive Statistic}

Table 4: Descriptive Statistics for study variables

\begin{tabular}{|l|l|l|l|}
\hline The Axis & Mean & $95 \%$ Confidence Interval for Mean* & Sig. \\
\hline Career guidance significance & 4.2 & $4.09-4.29$ & 0.09 \\
\hline Career guidance awareness & 1.14 & $1.08-1.2$ & 0.000 \\
\hline Reasons behind choosing specialty & 2.2 & $2.12-2.27$ & 0.000 \\
\hline Difficulties during selecting specialty & 4.1 & $3.9-4.1$ & 0.697 \\
\hline Methods of career guidance & 2.4 & $2.35-2.46$ & 0.000 \\
\hline
\end{tabular}

$95 \%$ Confidence Interval for Mean of the study population $=\bar{X} \mp t .0 .025,55 *$ Std.Error

According to table (4), it is obvious that (95\%) confidence interval for mean of the career guidance significance is between 4.09 as a lower bound and 4.29 as a higher pound, (95\%) confidence interval for mean of career guidance awareness is between 1.08 as a lower bound and 1.2 as a higher pound, (95\%) confidence interval for mean of reasons behind choosing specialty is between 2.12 as a lower bound and 2.27 as a higher pound, (95\%) confidence interval for mean of difficulties during selecting specialty is between 3.9 as a lower bound and 4.1 as a higher pound and (95\%) confidence interval for mean of methods of career guidance is between 2.35 as a lower bound and 2.46 as a higher pound. One-Sample T-test, with test value (4), has been selected because it is a suitable value that referred to a degree of "agreement". In this case, p-values have been divided into two types of results: the first type is statistically significant results where p-levels have been definitely less than .05 (so, the null hypothesis has been rejected) this result belongs to all variables except the variables of " Career guidance significance " $(\mathrm{p}=0.09)$ and "Difficulties during selecting specialty" $(\mathrm{p}=0.697)$, the result of these two variables represents the second type of results where p-level has been definitely more than .05 ( so the null hypothesis of this variable has been accepted). In other words, the awareness of students about these two variables equal or exceed the test value. On the other hand, there are significant differences between the other three variables and the standard level.

To assess the strength of correlation between pairs of career guidance variables as reported by the sampled students, the Pearson correlation has been used. The correlation coefficients showed that there is a statistically significant moderate to strong positive relationship between each pair of the study dimensions. 
Table 5. Correlations between career guidance's variables

\begin{tabular}{|c|c|c|c|c|c|}
\hline Variables & & \multirow[t]{2}{*}{$\begin{array}{l}\text { Career } \\
\text { guidance } \\
\text { awareness } \\
\\
\qquad 0.6^{* *}\end{array}$} & $\begin{array}{l}\text { Career } \\
\text { guidance } \\
\text { significance }\end{array}$ & $\begin{array}{l}\text { Reasons } \\
\text { behind } \\
\text { choosing } \\
\text { specialty }\end{array}$ & $\begin{array}{l}\text { Difficulties } \\
\text { during } \\
\text { selecting } \\
\text { specialty }\end{array}$ \\
\hline \multirow{3}{*}{$\begin{array}{c}\text { Career } \\
\text { guidance } \\
\text { significance }\end{array}$} & $r$ & & & & \\
\hline & $\begin{array}{l}\text { Sig. (2- } \\
\text { tailed) }\end{array}$ & $\overline{0.000}$ & & & \\
\hline & $\mathrm{N}$ & 142 & & & \\
\hline \multirow{3}{*}{$\begin{array}{l}\text { Reasons } \\
\text { behind } \\
\text { choosing } \\
\text { specialty }\end{array}$} & $r$ & 0.138 & $0.4 * *$ & & \\
\hline & $\begin{array}{l}\text { Sig. (2- } \\
\text { tailed) }\end{array}$ & 0.101 & $\overline{0.000}$ & & \\
\hline & $\mathrm{N}$ & 142 & 142 & & \\
\hline \multirow{3}{*}{$\begin{array}{l}\text { Difficulties } \\
\text { during } \\
\text { selecting } \\
\text { specialty }\end{array}$} & $r$ & $0.66^{* *}$ & $0.4^{* * *}$ & 0.041 & \\
\hline & $\begin{array}{l}\text { Sig. (2- } \\
\text { tailed) }\end{array}$ & 0.000 & $\overline{0.000}$ & 0.510 & \\
\hline & $\mathrm{N}$ & 142 & 142 & 259 & \\
\hline \multirow{3}{*}{$\begin{array}{l}\text { Methods of } \\
\text { career } \\
\text { guidance }\end{array}$} & $r$ & 0.497 - $^{* *}$ & $0.06-$ & 0.116 & $0.6-^{* *}$ \\
\hline & $\begin{array}{l}\text { Sig. (2- } \\
\text { tailed) }\end{array}$ & $\begin{array}{c}0.000 \\
\end{array}$ & 0.6 & 0.169 & $\overline{0.000}$ \\
\hline & $\mathrm{N}$ & 142 & 142 & 142 & 142 \\
\hline
\end{tabular}

Table (5) clarifies the following relationship between each pair of variables:

High correlation (marked relationship):

- The "career guidance awareness" and "career guidance significance" variables $(r=0.6, p=$ 0.000 );

- The "career guidance awareness" and "difficulties during selecting specialty" variables ( $r=$ $0.66, p=0.000)$;

- The "methods of career guidance" and "difficulties during selecting specialty" variables $(r=$ $0.6-, p=0.000$ ), this is a negative strong correlation.

- Moderate correlation (substantial relationship):

- The "career guidance awareness" and "methods of career guidance" variables $(r=0.497-, p=$ $0.000)$, this is a negative moderate correlation.

- The "career guidance significance" and "reasons behind choosing specialty" variables $(r=0.4$, $p=0.000)$;

- The "career guidance significance" and "difficulties during selecting specialty" variables $(r=$ $0.4, p=0.000)$.

- Non correlation (substantial relationship):

- The "career guidance awareness" and "reasons behind choosing specialty" variables $(r=0.138$, $p=0.101)$,

- The "career guidance significance" and "methods of career guidance" variables $(r=0.06-, p=$ 0.6 );

- The "reasons behind choosing specialty" and "difficulties during selecting specialty" variables $(r=0.041, p=0.510)$.

- The "reasons behind choosing specialty" and "methods of career guidance" variables $(r=0.116$, $p=0.169)$. 


\section{Study variables analysis}

Career guidance significance

The mean rank of all statements that measures the significance of career guidance is 4.19, showed in Table (6). This clarifies that career guidance has a high degree of significance at Egyptian tourism and hotels high institutes.

Table 6. Career guidance significance

\begin{tabular}{|l|c|c|}
\hline Statements & Mean & SD \\
\hline The career guidance and counseling services available at my institute & 3.90 & .6 \\
\hline $\begin{array}{l}\text { I agree to establish a career guidance unit at institute for selecting the specialty and } \\
\text { academic courses }\end{array}$ & 4.41 & .66 \\
\hline Total & 4.19 & .589 \\
\hline
\end{tabular}

Career guidance awareness

Concerning the career guidance awareness, the mean rank of all statements that measures the awareness of career guidance is 1.14. This reflects that career guidance awareness has a low degree at Egyptian tourism and hotels high institutes as shown at table (7).

Table 7. Career guidance awareness

\begin{tabular}{|c|c|c|}
\hline \multicolumn{1}{|c|}{ Statements } & Mean & \multicolumn{1}{c|}{ SD } \\
\hline I heard before about a program for students' career guidance & 1.11 & .32 \\
\hline Students' career guidance helps students choose the specialty and academic courses & 1.19 & .37 \\
\hline Total & 1.14 & .34 \\
\hline
\end{tabular}

Reasons behind choosing specialty

Table (8) showed that the highest mean score of that reasons is "The advice of friends and relative" at 3.04, followed by " The selection of students' near friends and colleagues to this specialty" at 2.6, " The desire to join the work of this specialty after graduation" at 2.12, " The tendency towards selecting the academic courses related to this field" at 1.9, finally, other reasons have been exemplified at 1.2 which is (The easily passed courses with guaranteed success).

Table 8 . Reasons behind choosing specialty

\begin{tabular}{|l|c|c|c|}
\hline \multicolumn{1}{|c|}{ Statements } & Mean & SD & Rank \\
\hline Your desire to join the work of this specialty after graduation & 2.12 & 1.8 & 3 \\
\hline Your tendency towards selecting the academic courses related to this field & 1.90 & 1.6 & 4 \\
\hline The advice of your friends and relatives & 3.04 & 1.8 & 1 \\
\hline The selection of your near friends and colleagues to this specialty & 2.60 & 1.7 & 2 \\
\hline Others & 1.20 & 0.83 & 5 \\
\hline \multicolumn{1}{|c|}{ Total } & 2.2 & .43 & \\
\hline
\end{tabular}

Difficulties during selecting specialty

As for the difficulties faced during selecting specialty, according to Egyptian tourism and hotels high institutes students' opinions, the results have indicated that the highest mean score of these difficulties are "Being obliged to choose the department by law and according to the ministerial decree" at 4.7, " There is no enough time for choosing the department as it is done very late just before the exam" at 4.47, "There are no enough information about the career of the specialty" at 4.26, " Unprofessional advice of the institute management" at 3.78, and others are illustrated at 2.85 such as (Misunderstanding of the departments work environment, misunderstanding of discrepancies among all departments and no care and interest from the institute about students' selection. For more clarification, see table (9). 
International Journal of Heritage, Tourism and Hospitality Vol. (13), No. (2), September, 2019 By: Faculty of Tourism and Hotels, Fayoum University

Table 9. Difficulties during selecting specialty

\begin{tabular}{|l|l|l|l|}
\hline \multicolumn{1}{|c|}{ Statements } & Mean & SD & Rank \\
\hline There are no enough information about the career of your specialty & 4.26 & 1.5 & 3 \\
\hline Unprofessional advice of your institute management & 3.78 & 1.7 & 4 \\
\hline $\begin{array}{l}\text { You have no enough time for choosing the department as it is done very, } \\
\text { late just before the exam }\end{array}$ & 4.47 & 1.3 & 2 \\
\hline $\begin{array}{l}\text { You are obliged to choose the department by law and according to the } \\
\text { ministerial decree }\end{array}$ & 4.70 & 0.98 & 1 \\
\hline Others & 2.85 & 1.9 & 5 \\
\hline \multicolumn{1}{|c|}{ Total } & 4.01 & .6 & \\
\hline
\end{tabular}

Methods of career guidance

Table (10) provides the methods of career guidance that have been used by students of Egyptian tourism and hotels high institutes. The results reveal that the most methods are: Arranging field visits and workshops in the work areas $(\mathrm{M}=3.79)$, followed by arranging personal/individual meetings with each student $(M=2.76)$. The lowest mean score are others $(M=1.14)$ such as Success stories of graduates who joined the tourism career, followed by arranging group meetings and seminars with students $(M=2.16)$, and "Guest speaker visits of industry people with awareness seminars (2.17).

Table 10. Methods of career guidance

\begin{tabular}{|l|l|l|l|}
\hline \multicolumn{1}{|c|}{ Statements } & Mean & \multicolumn{1}{c|}{ SD } & Rank \\
\hline Arranging field visits and workshops in the work areas & 3.79 & 1.8 & 1 \\
\hline Arranging personal/individual meetings with each student & 2.76 & 1.9 & 2 \\
\hline Arranging group meetings and seminars with students & 2.16 & 1.79 & 4 \\
\hline Guest speaker visits of industry people with awareness seminars & 2.17 & 1.79 & 3 \\
\hline Others & 1.14 & 0.7 & 5 \\
\hline \multicolumn{1}{|c|}{ Total } & 2.4 & .33 & \\
\hline
\end{tabular}

The teamwork members that students recommend for the career guidance unit

Table (11) identifies students' points of view in terms of the appropriate membership of career guidance unit. The highest rank has reached (65.16\%) which includes both academic and administrative staff. The second rank has recorded $(19.94 \%)$ which stands for graduates. The third category has noted $(12.10 \%)$ which is represented by employers and tourism experts. Finally, the fourth rank has got $(2.80 \%)$ which has been illustrated in representatives of tourism authorities and organizations.

Table 11 Career guidance teamwork members

\begin{tabular}{|l|l|l|l|}
\hline Teamwork members & Freq. & $\%$ & Rank \\
\hline$\underline{\text { Institute Staff }}$ & $\underline{161}$ & $\underline{65.16}$ & \\
Academic & 95 & 38.46 & 1 \\
Administrative staff & 66 & 26.70 & \\
\hline Graduates & 49 & 19.94 & 2 \\
\hline Employers and tourism experts & 30 & 12.10 & 3 \\
\hline Others & 7 & 2.80 & 4 \\
\hline Total & 247 & 100 & \\
\hline
\end{tabular}




\section{Second: Suggested Career Guidance Program Model}

Program structure and components is generally referenced to career guidance programs in some of the selected renowned worldwide universities and institutes. The tailored program consists of the following components:

1. Program Name

2. Program Identification

3. Program Objectives

4. Benefited Bodies (Beneficiaries)

5. General Principles

6. Program Main Role and Activities

7. Implementation Methods (Tools and Techniques)

8. Implementation Responsibilities

- Career Counseling Center

- Students and Graduates (Alumni) Center

- Advisory Board

9. Reviewing and Auditing

10. References

\section{1- Program Name:}

Referring to Students' Career Guidance Policy of Sultan Qaboos University, 2018, the following name is firstly suggested:

"Career Guidance policy for Students of Egyptian Tourism and Hotels High Institutes".

However, it is amended by interviewees to replace "policy" with "program" as according to their point of view, career guidance is regarded as a program, which is a part of a general major policy in Egypt which is "Youth employability". Thus, the final proposed name is "Career Guidance Program for Students of Egyptian Tourism and Hotels High Institutes"

\section{2- Program Identification:}

With reference to Career Guidance Program of Qatar University, 2017 and the Career Guidance and Counseling Program of Applied Sciences University in Bahrain, the following identification has been projected:

"Career guidance program is the program that is implemented in Tourism and Hotels High Institutes in Egypt that helps effectively students to better understand and explore their own personalities, as well as identifies labor market needs so as to take their appropriate career decisions, and confront all future job difficulties and challenges. Career guidance program is considered the most suitable method of acquiring the skills and capabilities that enable all beneficiaries to reach their successful professional future."

\section{3- Program Objectives:}

According to program objectives of Students' Career Guidance Policy of Sultan Qaboos University. 2018 and according to the Career Counseling Center of Fatima Jinnah Women University in Pakistan, the following objectives have been proposed:

- Provide professional career guidance services and facilities in compliance with the international career guidance standards

- Guarantee the quality of career guidance services in accordance with the quality measurements of the tourism and hospitality field

- Graduate highly qualified caliber that possess the professional skills and knowledge needed by the local and international labor market in tourism sector 
- Provide comprehensive services designed to help undergraduates, graduates, and alumni with their job search along with enhancing their educational, professional and personal development.

- Identify realistic and applicable main activities of career guidance and counseling center

\section{4- Benefited bodies (Beneficiaries):}

According to all referenced universities and educational institutes, the benefited bodies are stated to be students and graduates of Tourism and Hotels High Institutes in Egypt. However, interviewees added that the employers of tourism and hospitality corporates are important beneficiaries that must be considered. Accordingly, their involvement and consultation is highly important while preparing such a program

\section{5- General Principles:}

Based on Students' Career Guidance Policy of Sultan Qaboos University. 2018 and Career Guidance and Support Service Program of OHIO State University, 2019, the following principles have been stated:

- Career guidance services are necessary services that must be offered to all students and graduates of Egyptian Tourism and Hotels High Institutes in Egypt.

- Career guidance program is built on honesty, equity, transparency, students' confidentiality and integrity

- Career guidance program has to consider students' conditions and circumstances such as family effects, job market, geographic location, diversity background, personal circumstances, among others

- Career guidance center's staff is committed to offer all career guidance services to all benefited bodies as well as provide the financial support and manpower to guarantee the quality of the offered services

- Career guidance center's staff is dedicated to work as team players and in collaboration with students, graduates and academic staff

- Career guidance services are complimentary services offered to all beneficiaries

\section{6- Program main role and activities:}

According to Career Counseling Center at Fatima Jinnah Women University in Pakistan, program role and activities are recommended to be as follows: "Provide career guidance and consultation services to all students and graduates of tourism and hotels high institutes in Egypt through the following activities:

- Develop a career path, based on skills and interests of students.

- Gather all the available educational as well as occupational information to aid in developing this path.

- Help students select appropriate academic programs and other opportunities that maximize future educational and career options.

- Develop job-search and presentational skills.

- Establish networks with alumni, employers, organizations and other groups that offer potential professional opportunities.

- Utilize technology to enhance career development by making them aware of online job entries.

- Enhance professional communication skills for students.

- Find employment or a graduate opportunity that fits their goals.

- Prepare to manage their careers after the completion of university education. 
- Arrange education as well as job fairs to create industry-academia linkages.

- Help to identify the factors influencing the career Development and help to assess student's interest, abilities and values

\section{7- Implementation Methods (Tools and Techniques)}

According to the Student Career \& Alumni Development (SCAD) office of German University in Cairo (GUC) and the Students and Alumni Association of Glion Institute of Higher Education in Switzerland, the following techniques have been borrowed:

\section{First: Employer Services}

Tools and Techniques are represented in the following:

- Weekly Employment Announcements

- Internship E-announcement Posting

- Summer Internship Booklet

- Annual Internship \& Employment Fair

- Career Days

- Holding On-Campus Workshops

- On-Campus Interviews \& Tests

However, Internship has been refused and eliminated by interviewees as it does not exist in the High Institutes Study Plans in Egypt. Hence, the recommended tools are suggested to focus on Weekly Employment Announcements, Career Days, On-Campus Workshops, Interviews and Tests.

\section{Second: Students \& Alumni Services}

The following tools and techniques have been suggested to be utilized for practical understanding of the job market in Egypt \& worldwide, in addition to enhancing their perception about the professional life through various recruitment \& development activities.

Student Services include:

- Regular group Counseling Sessions

- Success Stories of Professional Graduates in the Labor Market

- Training \& Development Activities

- $\quad$ Employment Fair - passing experience \& knowledge to future graduates

- Simulated Interviews

- Invited Motivational Guest Speakers and Researches

- Alumni Services include:

- Regular Bulletins Containing Career Opportunities

- Scholarship Opportunities

- Development Workshops

- Counseling Services

- Alumni life-time E-mail Accounts

- Alumni Congregation

Moreover, there are other important general tools have also been recommended based on the utilized tools employed by the career centers in American University in Cairo (AUC) and to the Kyoto University Career Support which are:

- Career Web: It is an online career services are provided through a web-based career services management system. Career Web is regarded as a gateway to full-time jobs for graduates. It 
also keeps both students and graduates up-to-date with career-related workshops, on-campus recruiting visits and other career-related services

- Online Job Search tools

- One-on-one career counseling

- Book Lending through Library of books and materials to assist with job search activities

- Database of alumni and employers

- Career-building workshops, job preparation sessions, career fairs, mock-SPI examinations, and individual career counseling (On-on-one counseling)

\section{8- Implementation Responsibilities}

Implementation responsibilities are allocated by the following:

- Career Counseling Center

- Students and Graduates (Alumni) Center

- Advisory Board

\section{First: Career Counseling Center}

According to the Career Counseling Center (CCC) of Fatima Jinnah Women University, the purpose of $\mathrm{CCC}$ is proposed to narrow the gap between academies and industry and generate employability and marketable skills in students. It is established in compliance with a standardized criterion and clear role at institution level. CCC extends, various training, workshops, short courses, seminars for student to be more knowledgeable about career selection and path, as well as give them contact to markets and business trends and provide essential skills to increase their employability skills during their stay at universities.

CCC provides complete services designed to help undergraduates, graduates, and alumni with their job search along with improving their educational, professional and personal capabilities.

Moreover, it is recommended by interviewees that members of career counseling center should involve the following:

- Tourism Industry experts like professional managers, hoteliers and owners of hotels, restaurants and travel agents

- Academic professors in hospitality profession

- Academic staff working in the institute, representing the academic departments

- Administrative staff that coordinate and arrange the meetings, workshops and seminars

Second: Students and Alumni Center

According to Kyoto University Career support office, students and alumni center provides high quality services to assist in the identification of career opportunities and for the development of necessary skills required of students and researchers who are in the market for a job. Moreover, the center is committed to accept all comments and suggestions regarding the website, services and programs so that center may continue to improve them.

Students and Alumni Services

- Workshops \& guidance sessions

- Career and employment Fair

- One-on-one career counseling

- Disclosure of alumni list

Facilities 
- Computer terminals with internet connection

- Newspaper \& magazines

- Job listings accessible via website (on-campus only)

- Database of alumni and employers (student ID required, reference only, copying is prohibited.)

- Summaries of personal experiences by alumni (student ID required, reference only, copying is prohibited)

- Library of books and materials to assist with job search activities (student ID required; books loaned for one week, DVDs and some audio materials for one night)

Interviewees recommend that Students and Alumni Center should include the following membership:

- Employers of tourist establishments and hospitality properties

- Academic staff working in the institute

- Administrative staff working in the institute

- Professional graduates of the institute that work in the tourism and hospitality field

- Clever and unique students of the institute

Third: Advisory Board

It is recommended by interviewees that Advisory Board is composed of professionals holding key positions in the hospitality industry and related service industries. Their main role is to advise about the evolution and trends of the hospitality and tourism industry, which allows the institute to anticipate and adapt its career development programs accordingly.

\section{9- Reviewing and Auditing}

It is recommended by interviewees that there must be reviewing and auditing team to review and evaluate the quality and efficiency of career guidance program. Reviewing and auditing processes are done through questionnaires and interviews with program stakeholders and beneficiaries, as well as testing methods so as to prepare the reliable documents for quality control. Reviewing and Auditing are reported annually, specifically by the end of the academic year.

\section{0- References of the model}

- The Centre For Career Guidance of Sultan Qaboos University, 2018 https://www.squ.edu.om/ccg/

- Career Guidance and Counseling Program of Applied Sciences University in Bahrain https://www.asu.edu.bh/student/student-affair-evening-studies/office-of-alumni-and-carrierdevelopment/career-guidance-counseling/

- Career Guidance Program of Qatar University, 2017 http://www.qu.edu.qa/ar/students/support-and-development/career-development/careercounseling/career-counseling

- Career Counseling Center at Fatima Jinnah Women University in Pakistan http://fjwu.edu.pk/career-counseling-centre/

- Career Guidance and Support Service Program of OHIO State University, 2019 https://ccss.osu.edu/

- Student Career \& Alumni Development (SCAD) office of German University in Cairo (GUC) http://www.guc.edu.eg/en/facilities_services/scad.aspx 
- Glion Institute of Higher Education in Switzerland https://www.glion.edu/careersnetwork/alumni/

- Kyoto University Career Support Office, in Japan http://www.gssc.kyotou.ac.jp/career/en/about-us/

- Career centers in American University in Cairo (AUC) http://careerweb.caps.aucegypt.edu

\section{Third: Interview Analysis}

1- Do you support the idea of setting a program for career guidance at your institute?

Kindly support your answer with reasons and clarification

All of interviewees support the idea of setting a program for career guidance due to the following reasons:

- Students are generally unaware about the career options and job requirements in the tourism field. Consequently, most of them select the department and academic courses haphazardly through the absence of academic advising.

- Students of the Egyptian high institutes are mostly unable to identify their skills and personal abilities so as to employ them to meet the tourism and hospitality career prerequisites.

- Most of students have no experience about tourism industry environment and matching it with the social culture, beliefs and traditions. Accordingly, they choose the department which does not fit them.

- The new academic study plan contains varieties of minor courses that represent different tourism career options, the fact that make students confused and hesitant in selection

- Institutes' management let students select courses and specialty without the consultation and advice of tourism industry experts and specialists

2- What are the main difficulties confronting the implementation of career guidance program?

- Most of institutes do not have the professional human resources that are familiar with career guidance program and do not have experience in its management, thus, they are not capable of implementing such a program professionally

- Most of high institutes' students do not mentally recognize the significance of career guidance program and then, are not keen neither to be devoted to the program nor consider it as a priority.

- Some of the academic staff guide students to select particular specialization with no regard to their skills and capabilities

\section{3- What are your recommendations for making a successful career guidance program?}

- To set the career guidance program as a compulsory program dictated by the governmental authorized associations

- Set a policy and system of establishing the career guidance program in terms of the following:

- Prepare a mission and vision statement

- Identify the objectives and values

- Draw an organization chart of career guidance unit

- Identify criteria for selecting career guidance program members and stakeholders

- Prepare a job description for each member

- Prepare an action plan for implementation

- Assign a budget for financing the program on an annual basis 
- Set an assessment system to evaluate program effectiveness

- Involve institutes' graduates who joined tourism and hospitality field, with success stories, as essential members of the program

- Include tourism and hospitality employers and market experts as main participants

- Establish a media for the program to inform all beneficiaries about the schedule of seminars, workshops, meetings, training courses and any related events

- Build IT communication system utilizing the recent technological tools such as E-conference, social media groups chatting, electronic info-graph

- Prepare a complete program for receiving and analyzing the students feedback and comments

- Prepare an awareness campaign to increase students' awareness and background about the significance of career guidance program

4- What is your feedback about the proposed model of career guidance program?

All interviewees generally accepted the proposed model of career guidance program but providing the following modifications:

- Program Name: Replacing the word "policy" with the word "program" so as to be finally "Career Guidance Program for Students of Egyptian Tourism and Hotels High Institutes".

- Benefited Bodies (Beneficiaries): Employers of tourism and hospitality properties are important beneficiaries that must be considered with participation.

- Implementation Methods (Tools and Techniques): Internship programs have been refused and eliminated by interviewees as they do not existin in the High Institutes Study Plans in Egypt

- Implementation Responsibilities: Career guidance center should involve tourism experts, academic staff, professors and administrative staff. Moreover, students and alumni center should include employers, academic staff, distinguished students and professional graduates. Finally, it is important to add the Advisory Board as an important entity for implementation responsibilities

- Adding "Reviewing and Auditing" point as an essential components of career guidance program

\section{Research Recommendations:}

According to the above review of literature and analyses, the following recommendations have been proposed:

First: Recommendations for the Ministry of Higher Education (MHE):

- Study the proposed tailored career guidance program model for the possibility of implementation favor tourism and hotels high institutes

- Apply a new mechanism for setting an obligatory career guidance program for tourism and hotels high institute, in line with the suggested career guidance program model, so as to be mentioned in and added to the new study plan.

- Establish a career guidance board with the involvement of all tourism and hotels industry's stakeholders, taking in mind the participation of tourism labor market representatives and academic consultants. The main role of this board is to provide training, consultation, evaluation, amendment and sustainable development of tourism and hospitality career guidance program 
- Launch awareness campaigns among all tourism and hotels institutes for identification of tourism and hospitality career guidance as well as stressing on its importance

- Prepare an evaluation program for the assessment of career guidance program's work process in the tourism and hotels high institutes, to be done on an annual basis

- Implement, first, a pilot project on one of the Egyptian tourism and hotels high institutes, for applying an obligatory career guidance program. Then, prepare a SWOT analysis of career guidance program for further development in the future

- Prepare an obligatory career guidance decree to be aligned with the Egyptian higher education law and regulations

Second: Recommendations for the Egyptian Tourism and Hotels High Institutes:

- Include the career guidance program in the mission and vision statement of the tourism and hotels high institutes to be aligned with the institutes' strategies and objectives.

- Build a unit for career guidance with the involvement of tourism and hospitality academic staff, tourism labor market representatives, institutes' administrative staff, institutes' selected students and graduates

- Set a budget for career guidance program to cover the expenses and costs required for program work

- Prepare a quality system to carry out the career guidance process on a professional manner, taking in consideration the comparison to esteemed and reputable worldwide tourism and hospitality academic associations through mutual study visits and consultation

- Provide on-line career guidance activities and recruit specialized staff for IT and internet communication and follow up

- Conduct the tourism and hospitality career guidance and counseling sessions on a chronological and systematic basis, under strict supervision and control

- Prepare measurement criteria for the assessment of career guidance program works so as to evaluate its effectiveness and positive impact

- Build partnership with reputable five star hotels and travel agencies to implement mutual career guidance activities depending on the labor market experience

- Organize students' study visits to well-known tourism and hospitality market places such as hotels, restaurants, resorts, airline companies and travel agencies to build a market driven skills and professional knowledge of students.

- Organize guest speakers' sessions of tourism and hospitality experts and trade people working in the tourism market.

- Organize graduates' visits to tourism and hotels high institute to provide their advice to students and exchange experience as well as support the idea of "graduates' success stories" that illustrates a good example of professional candidates who graduate from tourism and hotels high institutes.

\section{References}

Adams, C. (2012). Calling and career counseling with college students: finding meaning in work and life. Journal of college counseling, 15 (1), 65.

Aird, R., Miller, E., Van Megen, K., \& Buys, L. (2010). Issues for students navigating alternative pathways to higher education: Barriers, access and equity. Brisbane: Queensland University of Technology. 
Alexitch, L. R. (2002). The role of help-seeking attitudes and tendencies in students' preferences for academic advising. Journal of College Student Development, 43, 5-19.

Alexitch, L. R., \& Page, S. (1997). Evaluation of academic and career counseling information and its relation to students' educational orientation. Canadian Journal of Counseling, 31, 205-218.

Allan, G., Moffett, J., and Robertson, P. (2013). Updating qualifications for the career guidance profession in Scotland: Navigating the maze. Journal of Perspectives in Applied Academic Practice, 1: 66-68.

Arshad, M.; Tahir, A.; Khan, M. \& Basit, A. (2018). Impact of Career Counseling \& Vocational Guidance on Employment in TVET Sector. International Journal of Human Resource Studies. 8 (1), 274-289

Baum, T. (1995) Managing Human Resources in the European Hospitality Industry: A strategic approach. London: Chapman \& Hall.

Bivand, P. (2012). Generation lost: Youth unemployment and the youth labor market. London: Touchstone Extras, Trade Union Congress.

Brown, D. (2007). Career Information, Career Counseling, and Career Development. Sydney: Pearson Education Inc.

Cardoso, P. M., Taveira, M. C., Biscaia, C. S. \& Santos, M. G. (2012). Psychologists' dilemmas in career counseling practice. International Journal for Educational and Vocational Guidance, Volume 12 (3), 225-241.

Chircu, S. (2014). Career counseling needs for students - a comparative study. Social and Behavioral Sciences 127 (2014) 549 - 553.

Choi, B., Lee, J., Kim, A., Kim, B., Cho, D., \& Lee, S. (2013). The economic value of career counseling services for college students in South Korea. The career development quarterly, 61 (2), p 168-178.

Choi, K., Buskey, W. \& Johnson, B. (2010). Evaluation of counseling outcomes at a university counseling centers: The impact of clinically significant change on problem resolution and academic functioning. Journal of Counseling Psychology, 57, 297-303.

Coetzee, M. \& Roythorne , H. (2012). Career Counseling and Guidance in the Workplace. A Manual for the Career Practitioners, 2nd ed. Cape Town: Juta.

Crisan, C., Pavelea, A., \& Ghimbuluţ, O. (2015). A need assessment on students' career guidance. Procedia-Social and Behavioral Sciences, 180 (2015), 1022-1029. doi: 10.1016/j.sbspro.2015.02.196.

Erasmus, B. J., Loedolff, P.V.Z., Mda, T.V. \& Nell, P.S. (2009). Managing Training and Development in South Africa, 5th ed. Cape Town: Juta.

Fabio, A., \& Bernaud, J. L. (2008). The help seeking in career counseling. Journal of Vocational Behavior, 72(1), 60-66.

Ferrera, A., Watson, J. \& Zizzi, S. (2017). Division I college student-athlete attitudes toward career counseling. Journal for the Study of Sports and Athletes in Education, 11(3), 175-192.

Getachew, A., \& Gobena, D. (2016). "Career Development among Undergraduate Students of Madda Walabu University, South East Ethiopia". Journal of Student Affairs in Africa, 4(2), 25-37.

Gibson, S., Oliver, L., and Dennison-Cooper, M. (2015). Mapping Careers Provision in Schools and Colleges in England. DfE Research report. 
Gore, J., Holmes, K., Smith, M., Lyell, A., Ellis, H., \& Fray, L. (2015). Choosing university: The impact of schools and schooling: Final report to the National Centre for Student Equity in Higher Education Perth: Teachers \& Teaching Research Program.

Gu, H., Kavanaugh, R. R., \& Cong, Y. (2007). Empirical studies of tourism education in China. Journal of Teaching in Travel \& Tourism, 7(1), 3-24.

Guo, T. Q. (2009). Research on university students' career planning issues and strategies [Original in Chinese]. Heilongjiang Researches on Higher Education, 4, 88-90.

Hartung, P. J. (2010). Practice and Research in Career Counseling and Development - 2009. The Career Development Quarterly 59 (2), 98-142.

Henson, R.K. (2001). Understanding Internal Consistency Reliability Estimates: A Conceptual Primer on Coefficient Alpha. Measurement and valuation in Counseling and Development, Vol. 34,177-188.

Hiebert, B. S., Collins, S., \& Robinson, J. (2001). Needs assessment for program planning and program development: A brief review. The Alberta Counselor, 26(1), 11-19.

Hooley, T. (2017). Moving beyond 'what works': Using the evidence base in lifelong guidance to inform policy making. In Schroder, K. and Langer, J. (Eds.) Wirksamkeit der Beratung in Bildung, Beruf und Beschäftigung (The Effectiveness of Counseling in Education and Employment). Bielefeld: W. Bertelsmann Verlag, pp. 25-35.

Hughes, D., Mann, A., Barnes, S-A., Baldauf, B. and McKeown, R. (2016). Careers Education: International Literature Review. London: Education Endowment Foundation.

Hunt, J. \& Eisenberg, D. (2010). Mental health problems and help-seeking behavior among college students. Journal of Adolescent Health, 46(1), 3-10.

ILO (2001) Human Resources Development, Employment and Globalization in the Hotel, Catering, and Tourism Sector. Geneve: ILO.

James, R., \& Devlin, M. (2006). Improving Indigenous outcomes and enhancing Indigenous culture and knowledge in Australian higher education. Canberra: Indigenous Higher Education Advisory Council.

Khamadi, J., Bowen, M., \& Oladipo, R. (2011). Factors determining career choice among Daystar University undergraduate students. Paper presented at the international conference on education at Kenyatta University, Kenya.

Kok, J. K., \& Low, S. K. (2017). Proposing a collaborative approach for school counseling. International Journal of School \& Educational Psychology, 5(4), 1-9.

Kunnen, E. S. (2013). The effects of career choice guidance on identity development. Educational Research International, 1-9.

Lamport, M. A. (1993). Student-faculty informal interaction and the effects on college student outcomes: A review of the literature. Adolescence, 28, 971-991.

Leach, J. K., \& Patall, E. A. (2013). Maximizing and counterfactual thinking in academic major decision making. Journal of Career Assessment, 21(3), 414-429.

Leppel, K. (2001). The impact of major on college persistence among freshmen. Higher Education, 41, pp. 327-342.

Li, P. (2002). Comparison and enlightenment of university students' career guidance in China and foreign countries [Original in Chinese]. Jiangsu Higher Education, 05, 103-104.

Li, X. L., \& Ye, Z. X. (2001). Overview of graduates' employment [Original in Chinese]. Guangzhou: Guangdong Higher Education Press. 
Long, Q. H., \& Song, Y. Q. (2007). Exploration of university students' comprehensive employment guidance mode [Original in Chinese]. Data of Culture and Education, 26, 154155.

Long, R. and Hubble, S. (2018). Careers Guidance in Schools, Colleges and Universities. Briefing Paper Number 07236, House of Commons Library.

Ma, Y. F. (2009). From margin to center: Evolutions of the career training for the undergraduate [Original in Chinese]. Journal of Hebei Normal University (Educational Science Edition), 11(3), 108-112.

Mporananayo, N. \& Andala, H. (2018). Career Guidance and Students' Academic Performance in Higher Learning Institutions in Rwanda. A Case Study of Nyarugenge District. IOSR Journal of Humanities and Social Science, 23(12), 72-80.

Mulvey, R. (2010). Career guidance in England: retrospect and prospect. British Journal of Guidance and Counseling, 34(1), 13-30.

Murdock, L. N., Duan, C., Nilsson, E. J. (2012). Emerging Approaches to Counseling Intervention: Theory, Research, Practice, and Training, The Counseling Psychologist, 40, 966-975.

Nauta, M. M., Epperson, D. L., \& Kahn, J. H. (1998). A multiple-groups analysis of predictors of higher level career aspirations among women in mathematics, science, and engineering majors. Journal of Counseling Psychology, 45, 483-496. doi:10.1037/0022-0167.45.4.483

Ng, E. S. W., \& Burke, R. J. (2006). The next generation at work-business students' views, values and job search strategy: Implications for universities and employers. Education and Training, 48(7), 478-492.

Oye, N., Obi, M., Mohd, T., Bernice, G. (2012). Guidance and Counseling in Nigerian Secondary Schools: The Role of ICT. I.J. Modern Education and Computer Science, 8, 2633.

Peterson, N. G., Mumford, M. D., Borman, W. C., Jeanneret, P. R., Fleishman, E. A., Levin, K. Y., Campion, M. A., \& Dye, D. M. (2001). Understanding work using the occupational information network (O*NET). Personnel Psychology, 54, 451-492.

Radulet, A. (2013). Student Career Orientation, Accent, Cluj-Napoca

Roney, S. and Oztin, P. (2007). Career Perceptions of Undergraduate Tourism Students: A Case Study in Turkey. Journal of Hospitality, Leisure, Sport and Tourism Education 6(1), 4 -17.

Santilli, S., Marcionetti, J., Rochat, S., Rossier, J., \& Nota, L. (2017). Career adaptability, hope, optimism, and life satisfaction in Italian and Swiss adolescents. Journal of Career Development, 44(1), 62-76.

Seung, N. (2014). Relationship between TVET System and Employment. New Frontiers of Educational Research, 9(1), 109-125.

Smith, S. M. (2001). A social cognitive approach to the career development of undergraduate students. The Delta Pi Epsilon Journal, 43(4), 200-208.

Sultana, R. G., \& Watts, A. G. (2008). Career guidance in the Middle East \& N. Africa. International Journal of Vocational Guidance. DOI 10.1007/s10775-007-9133-5.

Sun, J. Y. (2009). Thoughts on implementing comprehensive career education for college students [Original in Chinese]. Journal of Hubei University of Economics (Humanities and Social Sciences), 6(2), 151-152.

Sun, V. J. \& Yuen, M. (2012). Career Guidance and Counseling for University Students in China. International Journal for the Advancement of Counseling, 34, 202-210. 
Vertsberger, D., \& Gati, I. (2016). Career decision-making difficulties and help-seeking among Israeli young adults. Journal of Career Development, 43, 145-159.

Wang, J. R. (2008). The exploration of carrying out comprehensive career guidance for university students [Original in Chinese]. Journal of Aba Teachers College, 25, 46-52.

Watts, A. G. \& Fretwell, D. (2004). Public Policies for Career Development. Washington DC, World Bank.

Watts, A. G., \& Van Esbroeck, R. (2000). New skills for new futures: A comparative review of higher education guidance and counseling services in the European Union. International Journal for the Advancement of Counseling, 22, 173-187.

West, P. (2013). Department of Higher Education and Training, South Africa: Address at the launch of the Career Development Project of the ETDP SETA on Monday 28 October 2013 at the Birchwood Hotel \& OR Tambo Conference Centre in Boksburg.

Wooley, A. and Hooley, T. (2015). Further education learners' prior experience of career education and guidance: A case study of Chesterfield College. Journal of the National Institute for Career Education and Counseling, 35(1), 50-56.

Wu, N. (2008). Discussing the development direction of university career guidance from the plight of severe employment [Original in Chinese]. Science \& Technology Information, 25, $519-550$.

Yan, M. X. (2008). Ways of strengthening undergraduates' career plan counseling [Original in Chinese]. Journal of Zhejiang Youth College, 2, 32-34.

Yu, L. L. (2008). Discussing the mode of college students' career education in China [Original in Chinese]. Higher Education Research, 35, 182-183.

Zhao, C. T., \& Shen, X. Y. (2008). Thoughts on the improvement of college students' effectiveness on career education [Original in Chinese]. Journal of Fujian Education College, 07, 27-30.

\section{Arabic Reference}

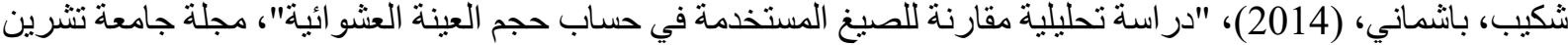
للبحوث والدراسات العلمية، سلسلة العلوم الاقتصادية والقانونية، المجلد (63)، العدد (5)، ص ص صلئة 85-100. 